\title{
PENGEMBANGAN OBJEK WISATA PANORAMA TERTINGGAL DI KABUPATEN TANAH DATAR
}

\author{
Momon dt. Tanamir \\ Program Studi Pendidikan Geografi STKIP PGRI Sumatera Barat \\ momondttanamir@gmail.com
}

\begin{abstract}
Abstrak
This research was motivated by the development of tourism in the district of Tanah Datar in recent years has decreased mainly attraction of natural scenery. This study aims to determine what strategies can be done in the development of attractions panorama in Tanah Datar. This research is classified in a qualitative study using SWOT analysis. The data used are primary data and secondary data. Mechanical withdrawal informants using purposive sampling technique. Data were analyzed using three stages, namely; data reduction, data presentation, and conclusion. Examination of the validity of data consisting of; extension of participation, diligence in observation, and triangulation. The results show that the strategy can be done to tourism development Panorama in Tanah Datar, among others; 1) Publish that some panoramas in Tanah Datar has used biased historical attractions history. 2) Increase the promotion via its website and location map attractions Tanah Datar. 3) Perform pruning of pine trees that have been blocking the view. 4) Improved cooperation between the Regional Government (Department of Tourism, Wali Nagari with business attractions. 5) Local governments must be able to draw up a budget to allocate infrastructure and maintenance so as to increase the waiter towards tourists.
\end{abstract}

Keywords: Development, attractions, Panorama

\section{PENDAHULUAN}

Indonesia merupakan salah satu negara kepulauan yang memiliki kekayaan alam yang sangat melimpah, yaitu potensi keaneka-ragaman hayati dan non hayati yang dimilikinya sehingga Indonesia dikenal sebagai negara dengan keanekaragaman hayati dan non hayati tertinggi di dunia. Dengan besarnya sumber daya alam hayati dan non hayati yang dimiliki Indonesia, sektor pariwisata termasuk salah satu sektor unggulan diIndonesia yang sangat berpotensi untuk dikembangkan karena dapat menghasilkan devisa bagi Negara dan juga dapat membuka lapangan kerja bagi masyarakat.

Dalam usaha untuk mengembangkan dan meningkatkan penyelenggaraan kepariwisataan, dilakukan pembangunan objek dan daya tarik wisata, baik dalam bentuk mengusahakan objek dan daya tarik wisata yang sudah ada maupun membuat objek-objek baru sebagai objek wisata dan mempunyai daya tarik wisata.

Secara etymologis "pariwisata" yang berasal dari bahasa sangsekerta, yang terdiri dari dua suku kata yaitu "pari" dan "wisata". Pari yang berarti banyak, berkali-kali atau berkeliling dan wisata berarti perjalanan. Istilah pariwisata pada umumnya sering digunakan dengan istilah "pengunjung atau visitor". Visitor adalah setiap orang atau kelompok orang yang datang ke suatu daerah atau negara lain dengan maksud apapun kecuali menerima upah (Bakaruddin, 2008:12). 
Kepariwisataan dalam artian sempit ialah lalu lintas orang-orang yang meninggalkan tempat kediaman untuk sementara waktu, untuk berpesiar di tempat lain semata- mata sebagai konsumen dari sebuah hasil perekonomian dan kebudayaan, guna memenuhi kebutuhan hidup dan budaya atau keinginan yang beraneka ragam dari pribadinya (Kurt Morgenroth dalam Bakaruddin, 2008:16). Dan A. Yoeti yang dikutip dari Maisardi (2005:10) mendefinisikan pariwisata adalah kegiatan perjalanan dengan tujuan untuk memperoleh kenyamanan.

Pembangunan dan perkem-bangan pariwisata nasional bertujuan meningkatkan taraf hidup masyarakat, terutama pada Daerah Tujuan Wisata (DTW). Secara menyeluruh tujuan tersebut dapat dirumuskan; sebagai devisa bagi negara, membuka lapangan kerja/kesempatan kerja, memperkenalkan kekayaan alam dan budaya bangsa, memupuk rasa cinta tanah air dan bangsa (Bakaruddin, 2008:01).

Pengembangan kepariwisataan juga bertujuan untuk memperkenalkan dan mendayagunakan keindahan alam dan kebudayaan Indonesia. Ini berarti, pengembangan pariwisata di Indonesia tidak terlepas dari potensi yang dimiliki oleh Indonesia untuk mendukung pariwisata tersebut. Pengembangan objek wisata dapat berjalan dengan baik apabila pengelolaannya dapat dilakukan dengan sebaik-baiknya. Pengeloaan objek wisata sangat berpengaruh terhadap perkembangan kepariwisataan karena lancar tidaknya perkembangan suatu objek pariwisata sangat ditentukan oleh bagaimana pengelolaan yang dilakukan.

Kabupaten Tanah Datar merupakan Daerah Tingkat II di Provinsi Sumatera Barat yang memiliki objek wisata yang sangat menarik dan memiliki potensi yang menjanjikan untuk dikembangkan sebagai daerah objek wisata, baik wisata alam, wisata sejarah maupun wisata budaya. Panorama alam di Kabupaten Tanah Datar perlu dikembangkan karena merupakan panorama alam yang indah dan sejuk karena terletak di daerah perbukitan dan pegunungan.

Perkembangan kepariwisataan di Kabupaten Tanah Datar dalam beberapa tahun terakhir mengalami penurunan. Dari hasil observasi yang dilakukan, hal tersebut disebabkan karena kurangnya terawatnya sarana prasarana yang sudah ada, kurangnya promosi terhadap objek wisata dan kurangnya partisipasi masyarakat di- sekitar daerah objek wisata.

Besarnya potensi yang dimiliki oleh objek wisata Panorama alam di Kabupaten Tanah Datar tetapi dari tahun ke tahun mengalami penurunan jumlah kunjungan wisatawan 
maka perlu rasanya untuk lebih dikembangkan. Dalam pencapaian tujuan dari penelitian yaitu menemukan strategi dalam pengembangan objek wisata Panorama di Kabupaten Tanah Datar, maka data yang terkumpul di lapangan dianalisis dengan menggunakan analisis SWOT. Analisis SWOT adalah analisis yang digunakan untuk melakukan analisis strategis dan untuk memahami posisi terkini suatu organisasi dalam lingkungannya (internal dan eksternal).

\section{METODOLOGI}

Jenis penelitian ini adalah deskriptif kualitatif, yaitu penelitian yang berusaha mengungkapkan bagaimana keberadaan objek secara apa adanya sesuai dengan kenyataan yang ditemui di lapangan. Arikunto (2006:12) mengemukakan bahwa penelitian kualitatif menunjukan bahwa pelaksanaan penelitian ini terjadi secara alamiah, apa adanya dalam situasi normal yang tidak dimanipulasi keadaan dan kondisinya dan dituntut keterlibatan peneliti secara langsung dilapangan.

Menurut Sugiyono (2005:1) metode penelitian kualitatif adalah metode penelitian yang digunakan untuk meneliti pada kondisi objek yang alamiah dimana penelitian kualitatif bertujuan membuat deskripsi atas sebuah fenomena sosial atau alam secara sistematis, faktual dan akurat.

Penelitian ini dilakukan di Kabupaten Tanah Datar, yaitu pada objek wisata panorama alam seperti; Panorama Tabek Patah, Panorama Puncak Pato dan Panorama Bukit. Subjek dalam penelitian kualitatif bukan dinamakan responden, tetapi sebagai nara sumber atau informan. Dalam penelitian ini teknik pengambilan informan menggunakan teknik nonprobability sampling yaitu teknik pengambilan sampel yang tidak memberikan peluang atau kesempatan yang sama bagi setiap unsur atau anggota populasi untuk dipilih menjadi sampel, dalam hal ini teknik yang digunakan adalah purposive sampling, adalah teknik pengambilan sampel sumber data dengan pertimbangan tertentu, misalnya orang tersebut yang dianggap paling tahu tentang apa yang kita harapkan (Sugiyono:2005).

Dalam memperoleh informasi tentang objek penelitian maka informan penelitian ini akan dibatasi pada beberapa orang diantaranya, yaitu: Dinas Pariwisata Kebudayaan dan Pariwisata Kabupaten Tanah Datar, Camat, Wali Nagari, Pengelola objek wisata, Ketua Pemuda, masyarakat setempat dan pengunjung.

Dalam penelitian kualitatif sumber data (informan) di pilih dengan mengutamakan teknik perspektif emic, artinya mementing-kan pandangan informan, yakni bagaimana 
mereka memandang dan menafsirkan dunia dari pendiriannya, dalam hal ini peneliti tidak bisa memaksakan kehendak untuk mendapatkan data yang diinginkan. Sumber data terbagi dua, yaitu sumber data primer dan sumber data sekunder. Data primer dapat diperoleh dari: a. Biro Pusat Statistik (BPS), b. Instansi pemerintah pembina dan pengembangan pariwisata, seperti Dinas Pariwisata, c. Pemuka Masyarakat, Ketua Pemuda, Camat, dan Wali Nagari, d. Masyarakat dan Pengunjung. Sedangkan data sekunder tidak langsung diberikan kepada pengumpul data, misalnya lewat orang lain atau lewat dokumen, wawancara, observasi dari pihak yang mengelola kepariwisataan.

Dalam pengumpulan data dalam penelitian ini, dilakukan dengan menggunakan tiga cara, yaitu; 1) wawancara (bebas dan terstruktur), 2) Observasi, dan 3) Dokumentasi. Teknik analisis data menggunakan tiga tahapan, yaitu; reduksi data, penyajian data, dan penarikan kesimpulan. Pemeriksaan keabsahan data terdiri dari; perpanjangan keikutsertaan, ketekunan dalam pengamatan, dan triangulasi.

\section{PEMBAHASAN}

Hasil penelitian dalam penelitian ini akan menemukan apa-apa saja strategi yang bisa dilakukan dalam pengembangan objek wisata di Kabupaten Tanah Datar. Berikut disajikan hasil penelitian mengenai kekuatan, kelemahan, peluang, ancaman dan strategi pengembangan.

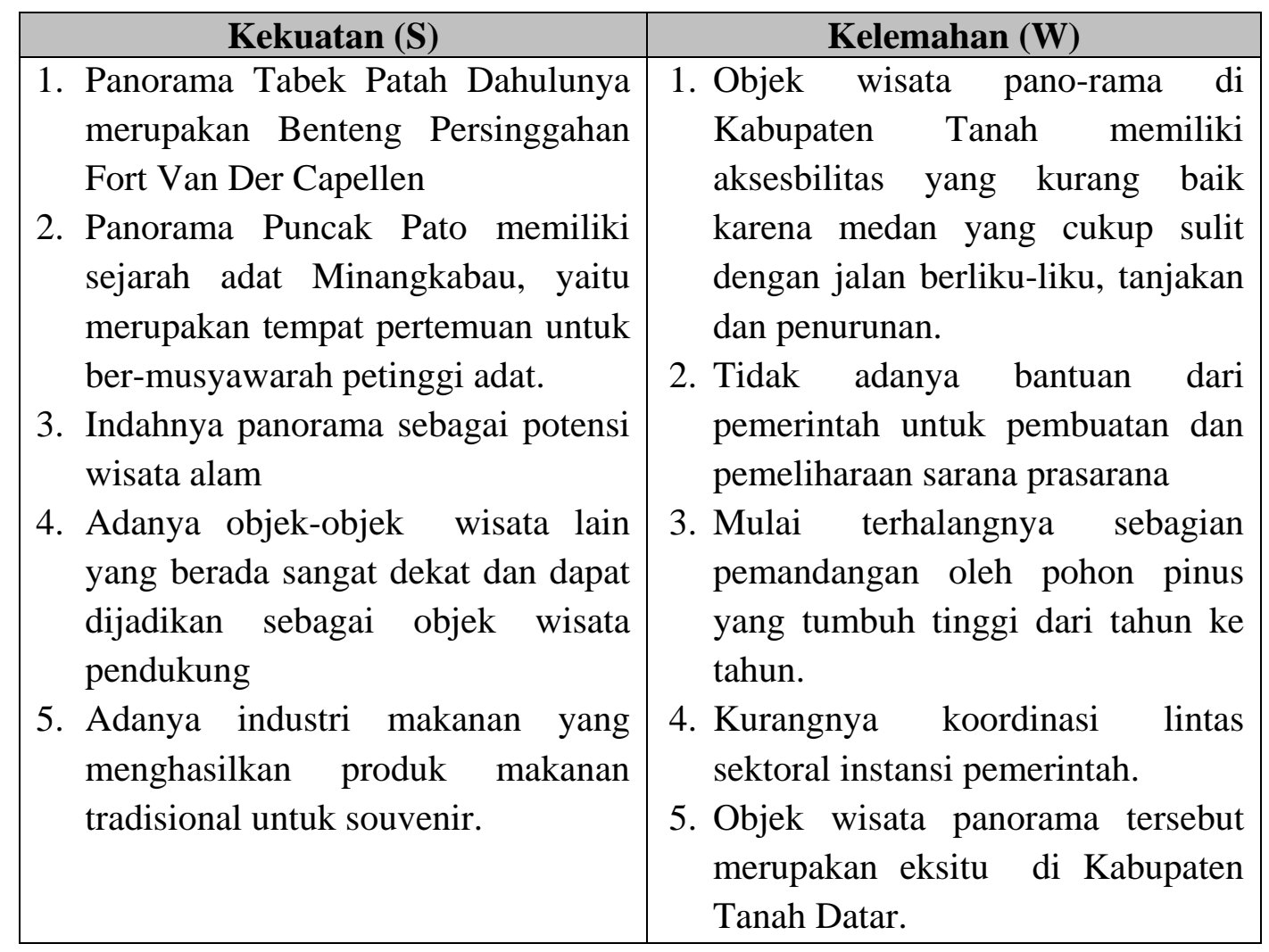




\begin{tabular}{|l|l|}
\hline Peluang (O) & \multicolumn{1}{|c|}{ Ancaman (T) } \\
\hline $\begin{array}{l}\text { 1. Adanya peta lokasi dan website yang } \\
\text { dibuat oleh pemerintah }\end{array}$ & $\begin{array}{l}\text { 1. Adanya objek wisata lain lebih } \\
\text { diperhatikan dan dikembangkan } \\
\text { pemerintah daerah. }\end{array}$ \\
$\begin{array}{l}\text { 2. Adanya potensi bahaya tsunami bagi } \\
\text { daerah-daerah dipesisir pantai } \\
\text { sehingga wisatawan lebih memilih } \\
\text { berwisata ke daerah pegunungan } \\
\text { atau perbukitan dari pada ke daerah } \\
\text { pantai. }\end{array}$ & \\
\hline
\end{tabular}

\section{Kekuatan Objek Wisata}

Dari analisis yang dilakukan, dapat diketahui bahwa yang menjadi kekuatan dari objek wisata panorama di Kabupaten Tanah antara lain:

a. Panorama Tabek Patah dahulunya merupakan benteng persinggahan Fort Van Der Capellen. Jadi, selain mempunyai daya tarik keindahan alam, Panorama Tabek Patah juga bisa menarik wisatawan sebagai objek peninggalan sejarah.

b. Panorama Puncak Pato memiliki sejarah adat Minangkabau, yaitu merupakan tempat pertemuan untuk bermusyawarah petinggi adat, yaitu “Tigo Tunggu Sajarangan”.

c. Panorama alam di Kabupaten Tanah merupakan sebuah panorama dengan potensi keindahan alam, yaitu hamparan pemandangan alam yang indah dan luas. Selain keindahan alamnya, panorama alam di Kabupaten Tanah mempunyai udara yang sejuk karena terletak di pergunungan.

d. Panorama alam di Kabupaten Tanah mempunyai objek wisata lain yang dijadikan sebagai objek wisata pendukung. Jadi, selain menikmati keindahan alam Panorama alam di Kabupaten Tanah, wisatawan nantinya bisa juga mengunjungi objek-objek wisata pendukung ini yang lokasinya tidak jauh dari panorama-panorama alam di Kabupaten Tanah, seperti; Istana Basa Pagaruyung, Batu Angkek-Angkek, Danau Singkarak, Bukit Sundi, dan lain sebagainya.

e. Di daerah sekitar objek wisata juga terdapat industri makanan yang menyediakan berbagai jenis makanan tradisional. Jadi, diharapkan bisa menambah daya tarik objek wisata karena dengan adanya produksi makanan tradisional dari daerah objek wisata ini.

\section{Kelemahan Objek Wisata}

Adapun yang menjadi kelemahan objek wisata panorama di Kabupaten Tanah adalah disebabkan oleh faktor-faktor di bawah ini; 
a. Objek wisata panorama di Kabupaten Tanah memiliki aksesbilitas yang kurang baik karena medan yang cukup sulit dengan jalan berliku-liku, tanjakan dan penurunan. Kondisi tersebut menyebabkan wisatawan enggan berkunjung dan lebih memilih mengunjungi objek wisata lain.

b. Tidak adanya bantuan dana dari pemerintah daerah untuk pembuatan sarana prasarana baru atau melengkapi sarana prasarana yang sudah ada maupun bantuan dana untuk pemeliharaan terhadap sarana prasarana yang sudah ada. Dengan kondisi seperti ini, diindikasikan sebagai salah satu faktor yang menyebabkan terjadi penurunan kunjungan wisatawan.

c. Mulai terhalangnya sebagian pemandangan panorama oleh pohon pinus yang tumbuh tinggi dari tahun ke tahun. Kondisi ini menyebabkan wisatawan yang berkunjung merasa agak kecewa karena tidak bisa melihat semua pemandangan yang ada karena terhalang oleh pohon pinus tersebut.

d. Kurangnya koordinasi lintas sektoral instansi pemerintah. Keadaan ini dikarenkan oleh adanya otonomi daerah yang memberikan kesempatan kepada daerah untuk mengembangkan daerahnya sendiri.

e. Objek wisata panorama tersebut merupakan eksitu di Kabupaten Tanah Datar. Dikatakan eksitu karena objek wisata panorama ini tidak lagi merupakan objek wisata utama (insitu) Kabupaten Tanah Datar karena adanya objek wisata yang lebih menarik dan banyak dikunjungi oleh wisatawan.

\section{Peluang Objek Wisata}

Analisis objek wisata, dapat diketahui bahwa yang menjadi peluang bagi objek wisata di Kabupaten Tanah, adalah:

a. Sudah adanya peta lokasi dan website objek wisata yang dibuat oleh pemerintah pusat dan pemerintah daerah sebagi promosi potensi wilayah. Jadi, dengan adanya peta lokasi dan website ini diharapkan makin bertambahnya jumlah wisatawan yang berkunjung ke objek wisata.

b. Adanya potensi bahaya tsunami bagi objek wisata yang ber-lokasi di pesisir pantai karena sering terjadi gempa di laut yang berpotensi menimbulkan tsunami. Dengan keadaan tersebut, secara tidak langsung menyebabkan jumlah kunjungan wisatawan ke objek-objek wisata di pesisir pantai akan turun drastis. Jadi memberikan peluang kepada objek wisata panorama alam di pegunungan untuk menarik para wisatawan. 


\section{Ancaman Objek Wisata}

Adapun yang menjadi ancaman bagi objek wisata panorama di Kabupaten Tanah adalah adanya objek wisata lain yang lebih diperhatiakn dan dikembangkan oleh pemerintah daerah. Objek wisata panorama merupakan eksitu di Kabupaten Tanah Datar. Dikatakan eksitu karena objek wisata panorama ini tidak lagi merupakan objek wisata utama (insitu) Kabupaten Tanah Datar karena adanya objek wisata yang lebih menarik dan banyak dikunjungi oleh wisatawan. Adanya Objek wisata yang lebih diperhatian oleh pemerintah daerah, sehingga menyebabkan jumlah kunjungan ke objek wisata lain ikut menurun karena wisatawan lebih memilih berkunjung ke objek wisata yang dikembangkan. Karena dengan lebih diperhatikan dan dikembangkannya suatu objek wisata oleh pemerintah, pasti objek wisata tersebut lebih lengkap sarana dan prasarananya.

Selanjutnya, untuk menentukan strategi pengembangan objek wisata, maka dianalisis menggunakan analisis SWOT menggunakan matrik berikut:

\begin{tabular}{|c|c|c|}
\hline an (S) & & \\
\hline $\begin{array}{l}\text { 1. Tabek Patah } \\
\text { Dahulunya } \\
\text { merupakan Benteng } \\
\text { Persinggahan Fort } \\
\text { Van Der Capellen } \\
\text { 2. Panorama Puncak } \\
\text { Pato memiliki } \\
\text { sejarah adat } \\
\text { Minangkabau, yaitu } \\
\text { merupakan tempat } \\
\text { pertemuan untuk ber- } \\
\text { musyawarah petinggi } \\
\text { adat. } \\
\text { 3. Indahnya panorama } \\
\text { sebagai potensi } \\
\text { wisata alam } \\
\text { 4. Adanya objek-objek } \\
\text { wisata lain yang } \\
\text { berada sangat dekat } \\
\text { dan dapat dijadikan } \\
\text { sebagai objek wisata } \\
\text { pendukung industri } \\
\text { Adanya yang } \\
\text { makanan mangan yanan } \\
\text { menghasilkan } \\
\text { produk makanan }\end{array}$ & $\begin{array}{l}\text { 1. Objek wisata pano- } \\
\text { rama di Kabupaten } \\
\text { Tanah memiliki } \\
\text { aksesbilitas yang } \\
\text { kurang baik karena } \\
\text { medan yang cukup } \\
\text { sulit dengan jalan } \\
\text { berliku-liku, tanjakan } \\
\text { dan penurunan. } \\
\text { 2. Tidak adanya bantuan } \\
\text { dari pemerintah untuk } \\
\text { pembuatan dan } \\
\text { pemeliharaan sarana } \\
\text { prasarana } \\
\text { Mulai terhalangnya } \\
\text { sebagian } \\
\text { pemandangan oleh } \\
\text { pohon pinus yang } \\
\text { tumbuh tinggi dari } \\
\text { tahun ke tahun. } \\
\text { 4. Kurangnya koordinasi } \\
\text { lintas sektoral instansi } \\
\text { pemerintah. } \\
\text { 5.Objek wisata } \\
\text { panorama tersebut } \\
\text { merupakan eksitu di }\end{array}$ & $\begin{array}{l}\text { 1. Mempublikasikan } \\
\text { bahwa beberapa } \\
\text { panorama r di } \\
\text { Kabupaten Tanah } \\
\text { Datar memiliki } \\
\text { historis yang bias } \\
\text { dijadikan objek } \\
\text { wisata sejarah } \\
\text { 2. Meningkatkan } \\
\text { promosi mengenai } \\
\text { kelebihan-kelebihan } \\
\text { dibandingkan objek } \\
\text { wisata lain, yaitu } \\
\text { mempunyai peman- } \\
\text { dangan yang sangat } \\
\text { indah, memiliki } \\
\text { udara yang sejuk, } \\
\text { aksesbilitas yang } \\
\text { baik dan adanya } \\
\text { industri makanan } \\
\text { tradisional. } \\
\text { 3. Melakukan } \\
\text { pemangkasan }\end{array}$ \\
\hline
\end{tabular}




\begin{tabular}{|l|lc|l|}
\hline $\begin{array}{l}\text { tradisional untuk } \\
\text { souvenir. }\end{array}$ & $\begin{array}{l}\text { Kabupaten Tanah } \\
\text { Datar. }\end{array}$ & $\begin{array}{l}\text { terhadap pohon } \\
\text { pinus yang sudah } \\
\text { menghalangi } \\
\text { pemandangan. }\end{array}$ \\
\hline
\end{tabular}

\begin{tabular}{|c|c|c|}
\hline Peluang $(\mathrm{O})$ & Ancaman (T) & Strategi O-T \\
\hline $\begin{array}{l}\text { 1. Adanya peta lokasi } \\
\text { dan website yang } \\
\text { dibuat } \\
\text { pemerintah } \\
\text { 2. Adeh } \\
\text { bahaya tsunami bagi } \\
\text { daerah-daerah di } \\
\text { pesisir pantai } \\
\text { sehingga wisatawan } \\
\text { lebih memilih } \\
\text { berwisata ke daerah } \\
\text { pegunungan atau } \\
\text { perbukitan dari pada } \\
\text { ke daerah pantai. }\end{array}$ & $\begin{array}{l}\text { 1. Adanya objek wisata } \\
\text { lain lebih diperhatikan } \\
\text { dan dikembangkan } \\
\text { pemerintah daerah. }\end{array}$ & $\begin{array}{l}\text { 1. Peningkatan } \\
\text { kerjasama antara } \\
\text { Pemerintah Daerah } \\
\text { (Dinas Pariwisata, } \\
\text { Wali Nagari dengan } \\
\text { Pengelola Objek } \\
\text { Wisata. } \\
\text { 2. Pemerintah daerah } \\
\text { hendaknya dapat } \\
\text { menyusun anggaran } \\
\text { untuk } \\
\text { mengalokasikan } \\
\text { sarana prasarana dan } \\
\text { pemeliharaannya } \\
\text { sehingga dapat } \\
\text { meningkatan } \\
\text { pelayan terhadap } \\
\text { wisatawan. }\end{array}$ \\
\hline
\end{tabular}

Dari tabel analisi strategi SWOT di atas, dapat diringkas bahwa strategi yang dapat dilakukan untuk pengembangan objek wisata panorama di Kabupaten Tanah Datar adalah:

Pertama, Mempublikasikan bahwa beberapa panorama di Kabupaten Tanah Datar memiliki historis yang bias dijadikan objek wisata sejarah. Panorama Tabek Patah dahulunya merupakan benteng persinggahan Fort Van Der Capellen. Jadi, selain mempunyai daya tarik keindahan alam, Panorama Tabek Patah juga bisa menarik wisatawan sebagai objek peninggalan sejarah. Panorama Puncak Pato memiliki sejarah adat Minangkabau, yaitu merupakan tempat pertemuan untuk bermusyawarah petinggi adat, yaitu "Tigo Tunggu Sajaranga".

Kedua, Meningkatkan promosi melalui website dan peta lokasi objek wisata Kabupaten Tanah Datar mengenai kelebihan-kelebihan objek wisata panorama di Kabupaten Tanah dibandingkan objek wisata lain, yaitu mempunyai pemandangan yang sangat indah, memiliki udara yang sejuk, dan adanya industri makanan tradisional. 
Ketiga, Melakukan pemangkasan terhadap pohon pinus yang sudah menghalangi pemandangan sehingga pemandangan dari panorama alam di Kabupaten Tanah tidak terhalangi.

Keempat, Peningkatan kerjasama antara Pemerintah Daerah, Wali Nagari dengan Pengelola objek wisata sehingga pengembangan terhadap objek wisata dapat dilaksanakan (peningkatan koordinasi lintas sektoral).

Kelima, Pemerintah daerah diharapkan dapat menyusun dan menurunkan dana untuk mengalokasikan sarana prasarana dan pemeliharaan sehingga sarana prasarana bisa terlengkapi dan terpelihara dengan baik sehingga dapat meningkatan pelayanan terhadap wisatawan.

\section{KESIMPULAN}

Strategi pengembangan objek wisata panorama di Kabupaten Tanah dapat disimpulkan sebagai berikut:

1. Mempublikasikan bahwa beberapa panorama di Kabupaten Tanah Datar memiliki historis yang bias dijadikan objek wisata sejarah.

2. Meningkatkan promosi melalui website dan peta lokasi objek wisata Kabupaten Tanah Datar.

3. Melakukan pemangkasan terhadap pohon pinus yang sudah menghalangi pemandangan.

4. Peningkatan kerjasama antara Pemerintah Daerah (Dinas Pariwisata, Wali Nagari dengan Pengelola objek wisata.

5. Pemerintah daerah hendaknya dapat menyusun anggaran untuk mengalokasikan sarana prasarana dan pemeliharaannya sehingga dapat meningkatan pelayan terhadap wisatawan.

\section{DAFTAR PUSTAKA}

Arikunto. 2006. Prosedur Penelitian. Jakarta: PT Asdi Mahasatya.

Bakaruddin. 2008. Perkembangan Dan Permasalahan Kepariwisataan Padang: UNP Press.

Maisardi, 2005. Eksistensi Kawasan Pantai Air Manis Sebagai Objek Wisata Kota Padang, (Skripsi) FIS UNP. Padang.

Sugiyono, 2005. Statistika Untuk Penelitian. Bandung: 